\title{
The budget's message to medical science: Quick! Get a shovel!
}

Published at www.cmaj.ca on Feb. 5, 2009.

$\mathrm{T}$ he fiscal stimulus package released by the Canadian government and supported by the official opposition is an attempt to resuscitate a critically ill economy. It is largely calculated to defend jobs, through "shovel-ready" infrastructure projects, and to cushion the blow of joblessness by providing skills-retraining and more generous employment insurance. We can only hope that the economic stimulus will succeed, considering that, at a cost of $\$ 34$ billion in deficit spending, Canadians will be paying for it for a long time.

But how will all of these tax dollars help Canadians compete globally in tomorrow's economy? Will this budget help stimulate innovation, support knowledge-based sectors and prepare Canada for the new economy that will emerge?

There is great cause for concern that it will not. With a stroke of a pen, the 2009 budget could instead erase 7 years of brain gain after the years of brain drain in the mid-90s. The Canadian Institutes of Health Research and the 2 research councils will see a $\$ 147.9$ million cut, which is a $5.5 \%$ decrease in their budgets. Worse off still is Genome Canada, which, after receiving endowments of $\$ 100$ million in $2007^{1}$ and $\$ 140$ million in $2008,{ }^{2}$ failed to secure additional top-up funds in the 2009 budget. The Canada Research Chair program, which enables universities and research institutes to attract and retain some of the world's best scientists, also got no new money in the stimulus budget.

As a consequence, we fear that our patient, Canada's economy, will remain on life support. Although the budget offers some welcome support for research infrastructure and graduate training, the cuts to programs that directly support ideas endanger our country's future productivity and prosperity. In economics, as in clinical practice, treating acute deteriorations does not obviate the need for a long-term care plan. The crisis in Canada's resource sectors in particular, while urgent, is a reminder that government investment must aim to substitute science and technology industries for the volatile "found" wealth of oil, mining and forestry.

These cuts to science and technology arrive despite the federal government agreeing that deficit spending is fair game when stimulating the economy. In saying yes to deficits and stimulus, yet being lukewarm to science, the unmistakable message from Finance Minister Jim Flaherty is that science is unimportant in Canada's economy.

Meanwhile, the stimulus package in the United States could hardly be more different. Both the House and Senate agree on adding US\$3.9 billion of new money to the National Institutes of Health budget - a $13 \%$ increase. ${ }^{3}$ For the National Science Foundation, the House wanted US $\$ 3$ billion added but the Senate wanted "only" US $\$ 1.4$ billion, which is still a $23 \%$ increase.
Overall, the American Association for the Advancement of Science estimates that the US stimulus package will give an extra US\$11.9-\$13.2 billion for scientific research. That makes for an embarrassing comparison with Canada. Even after adjustment for differences in population, the increase in US research spending this year exceeds the total research spending of the Canadian Institutes for Health Research. It is telling that in his first hours in office, President Obama reversed the Bush-era ban on stem cell research, signalling to the world that the United States will value scientific inquiry over ideology. A clear vision is emerging: science and research, not political beliefs, are the keys to a better health future.

The United States is not alone. The United Kingdom, although also hit hard by the economic crisis, is continuing its investment in applied health research of $£ 1.7$ billion for the new National Institutes of Health Research in 2009/10 and has given additional funds for its bioscience strategy via the Medical Research Council. ${ }^{4}$ Both countries are signalling the importance of health, health research and biological sciences to the new economy that will emerge.

Budget 2009 may foreshadow the decline of the science and technology strategy. What can be done to prevent this decline? Above all, Canada's associations of health professionals and scientists will have to lobby harder, for that is how budgets are now made. Indeed, lobbying is too important to be left to individuals in their free time. Mutual interest argues for creating a new career and employment track for science policy professionals. With so few who can effectively communicate the importance of science, other sectors were far more effective in getting their messages heard by government.

The health sector itself may have simply miscalculated terribly to think that because the benefits of health research are self-evident, their budgets would remain secure and grow. As shown in a recent survey by Clark and colleagues in $C M A J,{ }^{5}$ Canada's federal politicians, regardless of party, worry that health research budgets are too low but do not believe that voters care. Clearly, health researchers and other stakeholders must ensure that politicians hear about the importance of research from their constituents. It is small wonder that funding is decreasing or that opposition parties in Parliament have not demanded more spending for knowledge-based sectors.

Next, health researchers and professionals as well as institutions and lobbyists must ensure that the public and politicians recognize that Canadian scientists and doctors are capable of home runs. Important medical treatments (recent examples include lamivudine for HIV/AIDS and montelukast for asthma) have been developed in Canada. The secrets of dangerous diseases, such as the sequence of the SARS virus genome, have been unveiled in Canada. Life-prolonging knowledge has been revealed here: the benefits of using 
ramipril ${ }^{6}$ or harms of using proton pump inhibitors in combination with clopidogrel ${ }^{7}$ in patients at risk of cardiovascular death were both discovered in Canada. Fundamental puzzles of biology have been solved here: the T-cell receptor was cloned in Canada; without this we would have only a murky understanding of why infectious diseases kill or are cured.

Health researchers and professionals as well as institutions and lobbyists have to narrate the clear link between high achievement in science and technology and economic prosperity. The notion that commodities such as oil will make Canada reliably and enduringly rich is nonsense, when in the United States, the House proposed a $162 \%$ increase to energy efficiency and alternative energy research and was promptly outbid by the Senate, which wanted a $214 \%$ increase. In the future, the sale of science and technology will actually supersede that of resources and commodities.

All stakeholders, including lobbyists, must show the link between medical research in Canada and medical care for Canadians. The country's medical schools are dependent on on talented doctors, who split their time between clinical duties, teaching and research. Cut research budgets and 2 things happen: doctor-researchers emigrate, and the schools lose their teachers and laboratories. This makes training opportunitites for academic leaders more scarce. As any Canadian unable to find a family doctor or specialist knows, the country still suffers from the last mass emigration. To lose further academic leaders and clinical researchers, just as Canada's population is aging and needs medical schools to increase their training capacity, is short-sighted to say the least.

Health professionals and scientists need to understand that Budget 2009 can only be viewed as nothing more than an early resuscitative effort to re-establish our long-term economic survival and well-being. Advocacy, public engagement and leadership to achieve a more cohesive vision will be required to convince governments to invest our hard-earned dollars in our country's brains rather than just its bones. Without greater investment in science and technology, Canada's future will start looking perilously like Russia's present - a country that has vast resources but outmoded technology. To create Canada's future, our government should borrow from the United Kingdom and Switzerland's present - countries that have few natural resources but are rich in pharmaceuticals and biotechnology.

\section{Paul C. Hébert MD MHSc}

Editor-in-Chief

Matthew B. Stanbrook MD PhD

Deputy Editor, Scientific

Ken Flegel MDCM MSc

Senior Associate Editor

Noni MacDonald MD MSc

Section Editor, Population and Public Health

Amir Attaran LLB DPhil

Associate Editor, Editorials

CMAJ

Competing interests: See www.cmaj.ca/misc/edboard.shtml for the EditorialWriting Team's statements. Paul Hébert is an employee of the Canadian Institutes of Health Research. The opinions expressed in this article are those of the authors and not of the Canadian Institutes of Health Research. Amir Attaran holds a Canada Research Chair in Law, Population Health and Global Development Policy.

\section{REFERENCES}

1. Budget 2007. Chapter 5 - A stronger Canada through a stronger economy: knowledge advantage. Ottawa $(\mathrm{ON})$ : Department of Finance Canada. Available: www.budget.gc.ca/2007/plan/bpc5d-eng.html (accessed 2009 Feb. 4).

2. Budget 2008. Chapter 3 - Economic leadership: investing in the future. Ottawa (ON): Department of Finance Canada. Available: www.budget.gc.ca/2008/plan /chap3c-eng.asp (accessed 2009 Feb. 4).

3. American Association for the Advancement of Science. Senate proposes $\$ 11.9$ billion for R\&D in stimulus, House approves $\$ 13.2$ billion. Washington (DC): The Association; 2009. Available: www.aaas.org/spp/rd/stim09s.htm (accessed 2009 Feb. 4).

4. Medical Research Council. Major boost for UK health research funding. London (UK): The Council; 2007. Available: www.mrc.ac.uk/Utilities/Documentrecord/index .htm?d=MRC004065 (accessed 2009 Feb. 5).

5. Clark DR, McGrath PJ, MacDonald N. Members' of Parliament knowledge of and attitudes toward health research and funding. CMAJ 2007;177:1045-51.

6. The Heart Outcomes Prevention Evaluation Study Investigators. Effects of an angiotensin-converting-enzyme inhibitor, ramipril, on cardiovascular events in highrisk patients. NEJM 2000;342:145-153.

7. Juurlink DN, Gomes T, Ko DT, et al. A population-based study of the drug interaction between proton pump inhibitors and clopidogrel [online early release 2009 Jan. 28]. CMAJ 2009;180(7). DOI:10.1503/cmaj.082001 